\title{
PENGENDALIAN GULMA DENGAN BEBERAPA JENIS MULSA PADA BEBERAPA VARITAS TANAMAN PADI SAWAH (Oryza sativa L.) DENGAN METODE SYSTEM OF RICE INTENSIFICATION (SRI)
}

\author{
Amir Mahmud ${ }^{1}$ \\ Email: amir.mahmud@um-tapsel.ac.id \\ ${ }^{1}$ Staf Pengajar Fakultas Pertanian Universitas Muhammadiyah Tapanui Selatan J1 \\ Raja Inal Siregar - Tanggal No 32, Padangsidimpuan 22716
}

\begin{abstract}
ABSTRAK
Penelitian ini dilakukan di Desa Purwodadi Kecamatan Padang Sidimpuan Batunadua Kota Padangsidimpuan Provinsi Sumatera Utara dari bulan Mei sampai dengan bulan Agustus 2017. Tujuan dari penelitian ini adalah untuk menguji beberapa jenis mulsa dalam mengendalikan gulma pada beberapa varietas tanaman padi sawah dengan metode System Of Rice Intensification. Percobaan ini menggunakan Rancangan Petak Terpisah (Split plot design) dalam pola RAK dengan dua faktor. Faktor utama adalah varietas padi sawah yang terdiri dari tiga taraf perlakuan yaitu varitas Aryze H6444, varitas Situ Bagendit dan varitas Siganteng. Faktor anak petak adalah penggunaan mulsa yang terdiri dari empat taraf perlakuan yaitu jerami padi, sekam padi, titonia dan mulsa plastik hitam.Varitas Aryze H6444 Gold dan varitas Siganteng menunjukkan hasil terbaik pada penggunaan mulsa plastik, sedangkan varitas Situ Bagendit menunjukkan hasil terbaik pada mulsa jerami padi. Jenis gulma Ludwigia octovalvis merupakan gulma yang mendominasi pada pemberian mulsa jerami padi, sekam padi dan mulsa plastik. Sedangkan pada mulsa Titonia jenis gulma yang mendominasi adalah gulma Eleusine indica. Penggunaan mulsa plastik lebih baik dari pada penggunaan mulsa Titonia, mulsa jerami padi dan sekam padi dalam menekan pertumbuhan gulma pada tanaman padi sawah dengan sistem SRI.
\end{abstract}

Kata Kunci : pengendalian gulma, jenis mulsa, beberapa varitas,metode SRI.

\section{PENDAHULUAN}

Budidaya padi SRI menerapkan empat komponen penting yaitu: bibit ditanam pada umur muda 8-12 hari setelah semai (HSS), bibit ditanam dengan satu bibit per titik tanam, bibit ditanam dengan jarak lebar $(25 \mathrm{~cm} \times 25 \mathrm{~cm}$ atau $30 \mathrm{~cm} \times$ $30 \mathrm{~cm})$ dan tanah sawah tidak digenangi tapi hanya dalam kondisi lembab atau macak-macak (Sujatna 2010). Sedangkan pada padi sawah konvensional yang dikenal selama ini menerapkan tanam padi dengan cara penggenangan, benih ditanam 5-6 bibit per titik tanam, dan usia benih ditanam padi umur 21-25 hari setelah semai (HSS).

Penerapan metode SRI terdapat permasalahan utama yaitu tingginya pertumbuhan gulma. Gulma pada tanaman padi sawah dalam metode SRI tumbuh menjadi lebih cepat karena kondisi tanah sawah yang tidak tergenang. Pengelolaan gulma memang masalah yang serius sepanjang tahun, dimana $36 \%$ kehilangan produksi padi akibat 
persaingan tanaman dengan gulma meskipun sudah dikendalikan secara intensif (Deptan 2007). Potensi kehilangan hasil panen akibat gulma yang tidak dikendalikan di seluruh dunia pada satu musim diperkirakan mencapai 45-95\%, dan tergantung kepada kondisi cuaca dan ekologi. Penurunan hasil padi akibat gulma berkisar antara 60-87 \% (FAO 2004), sedangkan data penurunan hasil padi secara nasional akibat gangguan gulma 15-42 \% untuk padi sawah dan 47-87 $\%$ untuk padi gogo (Pitoyo 2006).

Menurut Sukman dan Yakup (2002), gulma mengurangi hasil tanaman dalam persaingan mendapatkan cahaya, oksigen, dan $\mathrm{CO}_{2}$, serta makanan. Penurunan hasil tanaman tersebut diakibatkan karena gulma dapat menurunkan aktivitas pertumbuhan antara lain kerdilnya pertumbuhan tanaman, terjadi klorosis, kekurangan hara, serta terjadinya pengurangan jumlah dan ukuran organ tanaman. Gejala kekurangan unsur hara pada tanaman padi dapat mengakibatkan kegagalan total tanaman bibit, tanaman sangat kerdil, gejala-gejala pada daun yang bersifat khas, dan kelainan - kelainan yang timbul pada jaringan tanaman.

Gulma padi sawah menjadi permasalahan penting yang perlu dicarikan solusinya, termasuk gulma pada metode SRI. Pengendalian gulma padi sawah metode SRI di Indonesia sampai saat ini masih menggunakan herbisida (DISIMP 2005). Aplikasi herbisida banyak dilakukan pada intensifikasi pertanian pada dekade terakhir, namun makin banyak gulma yang resisten terhadap herbisida. Disamping itu pengaruh herbisida yang merusak lingkungan menjadi semakin meluas, tiga juta ton herbisida setiap tahun digunakan dalam sistem pertanian di dunia (Chung et al. 2003).
Food Agriculture Organization (2004), melaporkan salah satu konsep pengendalian gulma padi sawah yang ekonomis, efisien, efektif dan ramah lingkungan adalah menggunakan sisasisa tanaman atau bahan organik. Bahan organik yang biasa digunakan untuk pengendalian gulma dalam bentuk mulsa berupa hijauan tanaman, seperti: jerami padi, sekam padi, titonia, dan sisa tanaman lainnya. Sehingga dinyatakan bahwa jerami padi dan jagung dapat dijadikan menjadi suatu kajian yang perlu mendapat perhatian untuk pengendalian gulma pada tanaman padi sawah.

Salah satu cara meningkatkan produksi pertanian adalah dengan cara memanipulasi lingkungan tumbuh tanaman. Upaya memanipulasi lingkungan yang dapat dilakukan yaitu dengan pemulsaan. Mulsa merupakan material yang dihamparkan di permukaan tanah. Pemberian mulsa dapat secara langsung berpengaruh terhadap lingkungan tumbuh tanaman seperti mencegah erosi, munculnya gulma, serta meningkatkan kadar air tanah, suhu tanah, udara tanah dan refleksi sinar matahari (Umboh 2000).

Tujuan lain pemulsaan adalah untuk mengendalikan gulma. Menurut Sukman dan Yakup (2002) gulma perlu dikendalikan karena (1) menurunkan produksi akibat bersaing dalam peman-faatan sarana tumbuh, (2) menurunkan mutu hasil akibat kontaminasi dengan bagian-bagian gulma, (3) mengeluarkan senyawa alelopati yang dapat meng-hambat pertumbuhan tanaman, (4) menjadi inang bagi hama dan patogen yang menyerang tanaman, (5) meningkatkan biaya usaha tani akibat biaya penyiangan. Beberapa penelitian melaporkan bahwa biomassa tumbuhan seperti jerami padi serasah tumbuhan, 
termasuk alang-alang potensial diguna-kan sebagai mulsa (Mayun 2007).

Penelitian mengenai penggunaan mulsa untuk tanaman padi belum banyak dilakukan. Oleh karena itu, perlu dilakukan penelitian tentang pengen-dalian gulma dengan beberapa jenis mulsa pada beberapa varietas tanaman Padi Sawah (Oryza sativa $\mathrm{L})$ dengan metode System of Rice Intensification (SRI).

\section{BAHAN DAN METODE}

Penelitian ini dilaksanakan pada lahan sawah yang terletak di Desa Purwodadi Kecamatan Batunadua Kota Padangsidimpuan dengan ketinggian tempat $\pm 350 \mathrm{~m} \mathrm{dpl}$, waktu percobaan ini dilaksanakan pada bulan Mei 2017 dan selesai pada bulan Agustus 2017.

Penelitian ini dilaksanakan dengan menggunakan Rancangan Petak Terpisah (Split plot design) dalam pola RAK dengan dua faktor. Faktor utama adalah varitas padi sawah yang terdiri dari tiga taraf perlakuan, dan faktor anak petak yaitu penggunaan mulsa yang terdiri dari empat taraf perlakuan.

Petak utama (main plot): Beberapa varitas padi (V), terdiri dari 3 taraf :

$\mathrm{V}_{1}$ : Aryze H6444 Gold (hibrida)

$\mathrm{V}_{2}$ : Situ Bangendit (unggul)

$\mathrm{V}_{3}$ : Siganteng (lokal)

Anak petak (sub plot) : beberapa jenis mulsa (M), terdiri dari 4 taraf :

$\mathrm{M}_{1}$ : Mulsa jerami padi (6 ton/Ha)

$\mathrm{M}_{2}$ : Mulsa sekam padi (5 ton/Ha)

$\mathrm{M}_{3}$ : Mulsa Titonia (15 ton/Ha)

$\mathrm{M}_{4}$ : Mulsa Plastik

Dengan demikian terdapat 12 kombinasi perlakuan yang diulang sebanyak 3 kali ulangan, sehingga terdapat 36 unit percobaan. Model linier yang digunakan yaitu:

Yijk $=\mu+\rho_{\mathrm{k}}+\alpha_{\mathrm{i}}+\delta \mathrm{j}+(\alpha \delta)_{\mathrm{ij}}+\gamma \mathrm{ik}+$ cijk

Data hasil pengamatan disusun dalam anova untuk masing-masing peubah. Jika pengaruh perlakukan terhadap peubah diamati menunjukkan pengaruh yang nyata dapat dilanjutkan dengan uji beda rataan dengan uji DRMT pada taraf $5 \%$ (Gomez \& Gomez 1995).

Untuk analisa data pada penelitian ini dilakukan pengambilan contoh gulma dengan cara acak yaitu mengambil 12 petak secara acak kemudian pada setiap petak dilakukan pengamatan terhadap gulma yang ada. Sampel gulma dipisahkan menurut jenisnya dan dibungkus dan diberi label kemudian sampel gulma di keringkan dalam oven dengan suhu $105^{0} \mathrm{C}$ selama $12 \mathrm{jam}$, lalu ditimbang untuk mengetahui berat kering gulma. Pengamatan terhadap gulma dilakukan hanya sekali yaitu pada umur 40 hari setelah tanam. Pengamatan terdiri dari, jenis gulma, jumlah gulma, bobot kering gulma, dan dominansi gulma.

\section{HASIL DAN PEMBAHASAN}

\section{Jenis, Jumlah dan Bobot Kering Gulma}

Gulma merupakan

permasalahan pada sistem penanaman padi SRI. Gulma dapat dengan mudah tumbuh pada areal pertanaman sehingga akan dapat menyebabkan kompetisi dalam perebutan unsur hara dari dalam tanah antara tanaman padi dengan gulma. Berdasarkan hasil percobaan diperoleh hasil bahwa ada beberapa jenis gulma yang tumbuh. Jenis, jumlah dan bobot kering gulma pada masing-masing perlakuan dalam penelitian ini dapat dilihat pada Tabel 1. 
Tabel 1 Jenis, jumlah dan bobot kering gulma (g)

\begin{tabular}{|c|c|c|c|c|c|c|c|c|c|}
\hline \multirow{3}{*}{ No. } & \multirow{3}{*}{ Jenis Gulma } & \multicolumn{8}{|c|}{ Perlakuan } \\
\hline & & \multicolumn{2}{|c|}{$\begin{array}{c}\text { Mulsa Jerami } \\
\text { Padi }\end{array}$} & \multicolumn{2}{|c|}{$\begin{array}{c}\text { Mulsa Sekam } \\
\text { Padi } \\
\end{array}$} & \multicolumn{2}{|c|}{ Mulsa Titonia } & \multicolumn{2}{|c|}{ Mulsa Plastik } \\
\hline & & Jumlah & $\begin{array}{c}\text { Bobot } \\
\text { Kering (g) }\end{array}$ & Jumla & $\begin{array}{c}\text { Bobot } \\
\text { Kering (g) }\end{array}$ & Jumlah & $\begin{array}{c}\text { Bobot } \\
\text { Kering } \\
\text { (g) } \\
\end{array}$ & Jumlah & $\begin{array}{c}\text { Bobot } \\
\text { Kering } \\
(\mathrm{g}) \\
\end{array}$ \\
\hline 1 & Portulaca oleracea & 3.00 & 1.57 & 0.00 & 0.00 & 0.00 & 0.00 & 0.00 & 0.00 \\
\hline 2 & Amaranthus spinosus & 1.00 & 0.20 & 0.00 & 0.00 & 2.00 & 0.70 & 0.00 & 0.00 \\
\hline 3 & Eleusine indica & 6.00 & 0.54 & 27.00 & 21.45 & 61.00 & 20.65 & 7.00 & 4.16 \\
\hline 4 & Convolvulus arvensis & 1.00 & 0.13 & 3.00 & 0.00 & 0.00 & 0.00 & 0.00 & 0.00 \\
\hline 5 & $\begin{array}{l}\text { Commelina diffusa } \\
\text { Burm.f. }\end{array}$ & 0.00 & 0.00 & 0.00 & 1.07 & 1.00 & 0.00 & 0.00 & 0.00 \\
\hline 6 & Eclipta prostrata & 1.00 & 0.30 & 0.00 & 0.00 & 0.00 & 0.00 & 0.00 & 0.00 \\
\hline 7 & Ludwigia octovalvis & 24.00 & 46.56 & 72.00 & 128.75 & 44.00 & 36.18 & 25.00 & 39.91 \\
\hline 8 & Eclipta alba & 12.00 & 28.55 & 16.00 & 10.61 & 51.00 & 50.99 & 0.00 & 0.00 \\
\hline 9 & Echinachloa crus-galli & 9.00 & 7.68 & 11.00 & 87.79 & 0.00 & 0.00 & 0.00 & 0.00 \\
\hline 10 & Limnacharis flava & 1.00 & 1.40 & 0.00 & 0.00 & 2.00 & 0.07 & 3.00 & 14.39 \\
\hline 11 & Leersia hexandra & 1.00 & 0.92 & 0.00 & 0.00 & 0.00 & 0.00 & 0.00 & 0.00 \\
\hline 12 & Mitella nuda & 1.00 & 0.11 & 0.00 & 0.00 & 0.00 & 0.00 & 0.00 & 0.00 \\
\hline 13 & $\begin{array}{l}\text { Cynodon dactylon (L.) } \\
\text { Pers. }\end{array}$ & 0.00 & 0.00 & 1.00 & 0.57 & 3.00 & 3.30 & 0.00 & 0.00 \\
\hline 14 & Asystasia gangetica & 0.00 & 0.00 & 0.00 & 0.00 & 2.00 & 2.00 & 0.00 & 0.00 \\
\hline 15 & Aeschynomene aspera & 0.00 & 0.00 & 0.00 & 0.00 & 2.00 & 0.32 & 0.00 & 0.00 \\
\hline 16 & Ageratum conyzoides & 0.00 & 0.00 & 0.00 & 0.00 & $\begin{array}{c}16.0 \\
0\end{array}$ & 6.19 & 0.00 & 0.00 \\
\hline 17 & Digitaria ciliaris & 0.00 & 0.00 & 0.00 & 0.00 & 3.00 & 6.75 & 0.00 & 0.00 \\
\hline 18 & Titonia & 0.00 & 0.00 & 0.00 & 0.00 & 3.00 & 0.87 & 0.00 & 0.00 \\
\hline 19 & $\begin{array}{l}\text { Bolboschoenus } \\
\text { maritimus }\end{array}$ & 0.00 & 0.00 & 2.00 & 1,07 & 0.00 & 0.00 & 0.00 & 0.00 \\
\hline & Total & 60 & 87.96 & 130 & 251.31 & 190 & 128.02 & 35 & 58.46 \\
\hline
\end{tabular}

Pengamatan gulma dilakukan pada umur tanaman padi 42 hari setelah tanam. Berdasarkan Tabel 1 dapat diketahui bahwa ada 19 jenis gulma yang tumbuh di areal percobaan. Pada mulsa Titonia terdapat gulma Eulisine indica sejumlah 61 individu dengan bobot kering $20.65 \mathrm{~g}$, dan gulma Eclipta alba sejumlah 51 individu dengan berat kering 50,99 g. Gulma Eulisine indica lebih banyak dibanding dengan gulma Eclipta alba namun berat keringnya lebih rendah. Hal ini disebabkan oleh morfologi kedua gulma tersebut dimana gulma Eulisine indica lebih kecil dibanding dengan gulma Ecipta alba. Gulma Eulisine indica memiliki batang yang berongga sedangkan gulma Eclipta alba memiliki batang yang tidak berongga.
Pada penggunaan mulsa jerami, sekam padi dan mulsa plastik di dominansi oleh gulma Ludwigia octovalvis. Sedangkan pada penggunaan mulsa Titonia didominasi oleh gulma Eleusine indica. Terjadinya dominansi gulma Ludwigia octovalvis pada mulsa jerami padi, sekam padi dan mulsa plastik terhadap jenis gulma lainnya dikarenakan gulma tersebut dapat berkembang dengan stolon dan biji. Biji gulma Ludwigia octovalvis memiliki masa dormansi yang rendah serta dapat berkecambah tanpa membutuhkan cahaya.

Menurut Moenandir (1988), tumbuhan yang mempunyaialat perkembangbiakan stolon dan biji akan mempunyai pertumbuhan yang sangat pesat sehingga akan 
mendominasi daerah tersebut. Diperkuat oleh Sukman dan Yakup (2002), tumbuhnya gulma berkaitan dengan deposit biji didalam tanah dan kesesuaian lingkungan biji untuk berkecambah.

Pada mulsa Titonia didominasi oleh gulma Eulisine indica disebabkan oleh bahan mulsa yang digunakan dimana mulsa Titonia lebih cepat terdekomposisi dibandingkan dengan mulsa lainnya. Hal menyebabkan permukaan tanah lebih cepat terbuka sehingga cahaya matahari langsung kepermukaan tanah. Dengan terjadinya penyinaran yang langsung kepermukaan tanah menyebabkan perkecambahan biji gulma lebih cepat berkecambah.

Menurut Willcox (2012), Eulisine indica dapat tumbuh subur dengan cahaya matahari penuh, dan masih dapat tumbuh dilahan marginal. Sedangkan Lee dan Ngim, (2000) menjelaskan E.indica dapat berbunga sepanjang tahun dan setiap individunya mampu menghasilkan biji 140.000 biji setiap musimnya sehingga cepat dalam penyebarannya.

Secara umum jenis gulma utama dalam penelitian ini adalah Ludwigia octovalvis hal ini bedasarkan pada jumlah dan bobot kering yang tertinggi dibandingkan dengan jenis gulma lain. Gulma tersebut berpotensi mempengaruhi pertumbuhan vegetatif dan generatif tanaman, dan akhirnya akan menurunkan jumlah produksi.

Analisis Indeks Nilai Penting (INP) gulma pada sistem padi SRI dilakukan untuk menetapkan dominasi suatu jenis gulma terhadap jenis gulma lainnya atau dengan kata lain indeks nilai penting dapat menggambarkan kedudukan ekologis suatu jenis gulma kedalam komunitas berbagai jenis mulsa yang diuji. Setiap jenis mulsa mempunyai INP yang berbeda-beda. Adapun Nilai Indeks Penting gulma pada berbagai jenis mulsa dapat dilihat pada Tabel 2.

Tabel 2 Analisis indeks nilai penting gulma pada perlakuan beberapa mulsa

\begin{tabular}{llcccc}
\hline \multirow{2}{*}{ No. Jenis Gulma } & \multicolumn{4}{c}{ Mulsa } \\
& & $\begin{array}{c}\text { Jerami } \\
\text { Padi }\end{array}$ & $\begin{array}{c}\text { Sekam } \\
\text { Padi }\end{array}$ & Titonia & Plastik \\
\hline 1 & Portulaca oleracea L & 11.25 & 0.00 & 0.00 & 0.00 \\
2 & Amaranthus spinosus & 7.92 & 0.00 & 10.15 & 0.00 \\
3 & Eleusine indica & 22.51 & 40.46 & $\mathbf{4 5 . 7 5}$ & 45.07 \\
4 & Convolvulus arvensis & 7.92 & 8.94 & 0.00 & 0.00 \\
5 & Commelina diffusa Burm. f. & 0.00 & 0.00 & 5.07 & 0.00 \\
6 & Bolboschoenus maritimus L. Palla & 0.00 & 8.18 & 0.00 & 0.00 \\
7 & Eclipta prostrata L & 7.92 & 0.00 & 0.00 & 0.00 \\
8 & Ludwigia octovalvis (Jacq) & $\mathbf{5 8 . 7 7}$ & $\mathbf{7 4 . 5 5}$ & 36.80 & $\mathbf{1 2 1 . 5 7}$ \\
9 & Eclipta alba & 32.51 & 32.12 & 40.48 & 0.00 \\
10 & Echinachloa crus-galli (L) & 27.51 & 28.33 & 0.00 & 0.00 \\
11 & Limnacharis flava L & 7.92 & 0.00 & 5.60 & 33.64 \\
12 & Leersia hexandra Sw & 7.92 & 0.00 & 0.00 & 0.00 \\
13 & Mitella nuda L & 7.92 & 0.00 & 0.00 & 0.00 \\
14 & Cynodon dactylon (L.) Pers. & 0.00 & 7.42 & 10.67 & 0.00 \\
15 & Asystasia gangetica & 0.00 & 0.00 & 5.60 & 0.00 \\
16 & Aeschynomene aspera L. & 0.00 & 0.00 & 5.60 & 0.00 \\
17 & Ageratum conyzoides & 0.00 & 0.00 & 17.52 & 0.00 \\
\hline
\end{tabular}




\begin{tabular}{llcccc}
\hline 18 & Digitaria ciliaris & 0.00 & 0.00 & 10.67 & 0.00 \\
19 & Titonia & 0.00 & 0.00 & 6.13 & 0.00 \\
\hline
\end{tabular}

Hasil penelitian pada Tabel 2 dapat diketahui bahwa pada mulsa jerami padi INP Gulma tertinggi terdapat pada gulma Ludwigia octovalvis yaitu $58.77 \%$, pada mulsa sekam padi INP tertinggi terdapat pada gulma Ludwigia octovalvis yaitu 74.55 $\%$, pada mulsa titonia INP tertinggi terdapat pada gulma Eleusine indica yaitu $45.75 \%$. Sedangkan mulsa plastik INP tertinggi terdapat pada gulma Ludwigia octovalvis yaitu $121.57 \%$.

Jenis gulma yang memiliki INP tertinggi pada jenis mulsa yang di uji menunjukkan bahwa jenis gulma ini memiliki peranan penting dibanding jenis lain, dengan kemampuan gulma ini bertahan hidupdan berkembang baik dapat dilihat dari jumlah nilai pentingnya. Semakin tinggi indeks nilai penting suatu jenis gulma maka semakin besar penguasaannya dalam komunitas. Beragamnya nilai INP dari berbagai jenis gulma yang ada pada masing-masing perlakuan mulsa menun-jukkan adanya pengaruh lingkungan tempat tumbuh seperti kelembaban, suhu dan kompetisi, seperti persaingan akan hara, sinar matahari dan ruang tumbuh dengan jenis-jenis lainnya yang sangat mempengaruhi pertumbuhan tanaman.

Rendahnya persaingan gulma dengan tanaman juga disebabkan oleh kondisi curah hujan selama pelaksanaan penelitian. Penelitian di mulai pada bulan Mei 2017 dimana curah hujan sangatlah rendah yaitu $163.4 \mathrm{~mm}$ dengan julah hari hujan sebanyak 7 hari sehingga pertumbuhan gulma menjadi lebih terhambat. Hal ini sesuai pendapat Jatmiko et al. (2002) gulma berinteraksi dengan tanaman melalui persaingan untuk mendapatkan satu atau lebih faktor tumbuh yang terbatas seperti cahaya, hara, dan air. Tingkat persaingan bergantung pada curah hujan, kondisi tanah, kerapatan gulma, pertumbuhan gulma, serta umur tanaman budidaya saat gulma mulai bersaing.

Analisis dominasi gulma pada sistem padi SRI dilakukan untuk mengetahui bagaimana sebaran gulma yang tumbuh pada berbagai jenis mulsa yang diuji. Setiap jenis mulsa mempunyai jumlah dan jenis gulma yang berbeda-beda.

Tabel 3 Analisis summed dominance ratio gulma pada perlakuan beberapa mulsa

\begin{tabular}{llcccc}
\hline No. & \multicolumn{1}{c}{ Jenis Gulma } & $\begin{array}{c}\text { Mulsa } \\
\text { Perami } \\
\text { Padi }\end{array}$ & $\begin{array}{c}\text { Sekam } \\
\text { Padi }\end{array}$ & Titonia & Plastik \\
\hline 1 & Portulaca oleracea L & 5.63 & 0.00 & 0.00 & 0.00 \\
2 & Amaranthus spinosus & 3.96 & 0.00 & 5.07 & 0.00 \\
3 & Eleusine indica & 11.25 & 20.23 & $\mathbf{2 2 . 8 7}$ & 22.53 \\
4 & Convolvulus arvensis & 3.96 & 4.47 & 0.00 & 0.00 \\
5 & Commelina diffusa Burm. f. & 0.00 & 0.00 & 2.54 & 0.00 \\
6 & Bolboschoenus maritimus L. Palla & 0.00 & 4.09 & 0.00 & 0.00 \\
7 & Eclipta prostrata L & 3.96 & 0.00 & 0.00 & 0.00 \\
8 & Ludwigia octovalvis (Jacq) & $\mathbf{2 9 . 3 8}$ & $\mathbf{3 7 . 2 7}$ & 18.40 & $\mathbf{6 0 . 7 9}$ \\
9 & Eclipta alba & 16.25 & 16.06 & 20.24 & 0.00 \\
10 & Echinachloa crus -galli (L) & 13.75 & 14.17 & 0.00 & 0.00 \\
\hline
\end{tabular}




\begin{tabular}{llllll}
\hline 11 & Limnacharis flava $L$ & 3.96 & 0.00 & 2.80 & 16.82 \\
12 & Leersia hexandra $S w$ & 3.96 & 0.00 & 0.00 & 0.00 \\
13 & Mitella nuda L & 3.96 & 0.00 & 0.00 & 0.00 \\
14 & Cynodon dactylon (L.) Pers. & 0.00 & 3.71 & 5.34 & 0.00 \\
15 & Asystasia gangetica & 0.00 & 0.00 & 2.80 & 0.00 \\
16 & Aeschynomene aspera L. & 0.00 & 0.00 & 2.80 & 0.00 \\
17 & Ageratum conyzoides & 0.00 & 0.00 & 8.76 & 0.00 \\
18 & Digitaria ciliaris & 0.00 & 0.00 & 5.34 & 0.00 \\
19 & Titonia & 0.00 & 0.00 & 3.06 & 0.00 \\
\hline
\end{tabular}

Hasil percobaan pada Tabel 3 dapat diketahui bahwa pada mulsa jerami padi dimana SDR tertinggi terdapat pada gulma Ludwigia octovalvis yaitu 29.38. Pada mulsa sekam padi dimana SDR tertinggi terdapat pada gulma Ludwigia octovalvis yaitu 37.27. Pada mulsa titonia dimana SDR tertinggi terdapat pada gulma Eleusine indica yaitu 22.87. Sedangkan mulsa plastik dimana SDR tertinggi terdapat pada gulma Ludwigia octovalvis yaitu 60.79 .

Jika dibandingkan jenis mulsa yang diuji maka jumlah gulma yang terendah terdapat pada mulsa plastik (3 jenis gulma) sedangkan jumlah gulma tertinggi terdapat pada mulsa Titonia (12 jenis gulma). Walaupun mulsa plastik menunjukkan jumlah gulma terendah namun nilai INP dan SDR menunjukkan nilai tertinggi setelah nilai INP dan SDR pada mulsa sekam padi sedangkan nilai INP dan SDR terendah terdapat pada mulsa titonia.

Berdasarkan hasil percobaan ini bahwa ada dua jenis gulma yang terdapat pada seluruh jenis mulsa yaitu Eleusine indica,dan Ludwigia octovalvis. Hal ini mengindikasikan bahwa gulma ini merupakan gulma yang dominan pada berbagai jenis mulsa. Ludwigia octovalvis merupakan gulma yang memiliki nilai INP dan SDR tertinggi jika dibandingkan dengan jenis gulma lainnya. Ludwigia octovalvis tidak tergolong gulma teki dan gulma rumput.

Hasil percobaan ini berbeda dengan penelitian Zulmardi (2016), yaitu jenis gulma yang paling mendominasi pada padi SRI adalah Cyperus Sp. sedangkan pada penelitian ini yang paling mendominasi adalah Ludwigia octovalvis. Hal ini dapat terjadi karena perbedaan lokasi tanam yang menyebabkan jenis gulma yang tumbuh juga berbeda. Hal ini ada kaitannya dengan jumlah seed bank gulma yang terdapat di dalam tanah yang mana daerah yang berbeda akan menunjukkan seed bank yang berbeda juga.

Setelah dilakukan evaluasi gulma berdasakan jenis mulsa, hal selanjutnya adalah dengan melakukan pengelompokan gulma yang tumbuh berdasarkan jenis varitas. Hasil pengamatan terhadap jenis, jumlah dan bobot kering gulma berdasarkan varitas yang diuji dapat dilihat pada Tabel 4. 
Tabel 4 Jumlah dan bobot kering gulma pada beberapa varitas

\begin{tabular}{|c|c|c|c|c|c|c|c|}
\hline \multirow{3}{*}{ No. } & \multirow{3}{*}{ Jenis Gulma } & \multicolumn{6}{|c|}{ Perlakuan } \\
\hline & & \multicolumn{2}{|c|}{$\begin{array}{c}\text { Aryze H6444 } \\
\text { Gold }\end{array}$} & \multicolumn{2}{|c|}{ Situ Bangendit } & \multicolumn{2}{|c|}{ Siganteng } \\
\hline & & Jumlah & $\begin{array}{c}\text { Bobot } \\
\text { Kering } \\
(\mathrm{g}) \\
\end{array}$ & Jumlah & $\begin{array}{c}\text { Bobot } \\
\text { Kering } \\
(\mathbf{g})\end{array}$ & Jumlah & $\begin{array}{c}\text { Bobot } \\
\text { Kering } \\
\text { (g) } \\
\end{array}$ \\
\hline 1 & Portulaca oleracea $\mathrm{L}$ & 0 & 0.00 & 3 & 1.57 & 0 & 0.00 \\
\hline 2 & Amaranthus spinosus & 1 & 0.38 & 1 & 0.20 & 1 & 0.32 \\
\hline 3 & Eleusine indica & 49 & 13.03 & 30 & 5.81 & 22 & 27.96 \\
\hline 4 & Convolvulus arvensis & 0 & 0.00 & 3 & 0.00 & 1 & 0.13 \\
\hline 5 & Commelina diffusa Burm. f. & 0 & 0.00 & 1 & 0.21 & 0 & 0.00 \\
\hline 6 & $\begin{array}{l}\text { Bolboschoenus maritimus } \\
\text { L. Palla }\end{array}$ & 2 & 1.07 & 0 & 0.00 & 0 & 0.00 \\
\hline 7 & Eclipta prostrata $\mathrm{L}$ & 1 & 0.30 & 0 & 0.00 & 0 & 0.00 \\
\hline 8 & Ludwigia octovalvis (Jacq) & 50 & 116.50 & 86 & 114.71 & 33 & 45.67 \\
\hline 9 & Eclipta alba & 22 & 8.11 & 24 & 36.37 & 29 & 20.19 \\
\hline 10 & Echinachloa crus-galli (L) & 8 & 26.65 & 2 & 6.98 & 10 & 61.84 \\
\hline 11 & Limnacharis flava $L$ & 4 & 15.79 & 0 & 0.00 & 2 & 0.07 \\
\hline 12 & Leersia hexandra $S w$ & 1 & 0.92 & 0 & 0.00 & 0 & 0.00 \\
\hline 13 & Mitella nuda L & 1 & 0.11 & 0 & 0.00 & 0 & 0.00 \\
\hline 14 & Cynodon dactylon (L.) Pers. & 1 & 2.22 & 3 & 1.65 & 0 & 0.00 \\
\hline 15 & Asystasia gangetica & 2 & 2.00 & 0 & 0.00 & 0 & 0.00 \\
\hline 16 & Aeschynomene aspera $\mathrm{L}$. & 2 & 0.32 & 0 & 0.00 & 0 & 0.00 \\
\hline 17 & Ageratum conyzoides & 13 & 5.64 & 3 & 0.55 & 0 & 0.00 \\
\hline 18 & Digitaria ciliaris & 1 & 0.73 & 2 & 6.02 & 0 & 0.00 \\
\hline 19 & Titonia & 3 & 0.87 & 0 & 0.00 & 0 & 0.00 \\
\hline & Total & 161 & 194.64 & 158 & 174.07 & 98 & 156.18 \\
\hline
\end{tabular}

Berdasarkan pada Tabel 4 ada perbedaan jumlah gulma pada masingmasing varitas. Pada varitas Aryze H6444 Gold didominasi oleh jenis gulma Ludwigia octovalvis yaitu 50 tanaman dengan bobot kering 116,50 g, pada varitas Situ Bangendit didominasi oleh gulma Ludwigia octovalvis yaitu 86 tanaman dengan bobot kering 114,71 g, sedangkan pada varitas Siganteng didominasi oleh gulma Eclipta albayaitu 33 tanaman tetapi untuk bobot kering terberat pada gulma Echinachloa crus-galli yaitu 61,84 g. Banyak sedikitnya jumlah gulma akan berpengaruh terhadap produksi tanaman utama.

Jumlah jenis dan individu gulma jumlah lebih banyak pada varitas Aryze H6444 Gold dibandingkan pada varitas Situ Bangendit dan varitas Siganteng. Hal ini disebabkan oleh tinggi tanaman pada varitas Aryze H6444 Gold lebih rendah dibandingkan dengan varitas lainnya, sehingga permukaan tanah lebih banyak menerima cahaya matahari hal ini menyebabkan pertumbuhan gulma semakin cepat. Menurut Prawiranata et al., (1981). Apabila lingkungan subur, air tersedia dan suhu sesuai maka cahaya matahari merupakan faktor pembatas pertumbuhan tanaman.

Analisis selanjutnya adalah melakukan pengamatan terhadap dominasi gulma berdasarkan varitas.Hal ini dilakukan untuk mengetahui apakah ada kecenderungan dominasi gulma pada varitas tertentu berdasarkan varitas yang digunakan dalam percobaan ini. Hasil percobaan terhadap dominasi 
gulma pada varitas Aryze H6444 Gold dapat dilihat pada Tabel 5.

Tabel 5 Analisis dominasi gulma sistem SRI berdasarkan varitas Aryze H6444 Gold

\begin{tabular}{|c|c|c|c|c|c|c|c|c|}
\hline \multirow{2}{*}{ No. } & \multirow{2}{*}{ Jenis Gulma } & \multicolumn{7}{|c|}{ Varitas Aryze H6444 Gold } \\
\hline & & $\mathbf{D}$ & $\mathbf{F}$ & FR & $\mathbf{K}$ & KR & INP & SDR \\
\hline 1 & Amaranthus spinosus & 1 & 0.25 & 3.70 & 0.56 & 0.62 & 4.32 & 2.16 \\
\hline 2 & Eleusine indica & 49 & 0.75 & 11.11 & 27.22 & 30.44 & 41.55 & 20.77 \\
\hline 3 & $\begin{array}{l}\text { Bolboschoenus maritimus } \\
\text { L. Palla }\end{array}$ & 2 & 0.25 & 3.70 & 1.11 & 1.24 & 4.95 & 2.47 \\
\hline 4 & Eclipta prostrata $\mathrm{L}$. & 1 & 0.25 & 3.70 & 0.56 & 0.62 & 4.32 & 2.16 \\
\hline 5 & Ludwigia octovalvis Jacq & 50 & 1.00 & 14.81 & 27.78 & 31.06 & 45.87 & 22.94 \\
\hline 6 & Eclipta alba & 22 & 0.75 & 11.11 & 12.22 & 13.67 & 24.78 & 12.39 \\
\hline 7 & Echinachloa crus-galli $\mathrm{L}$. & 8 & 0.50 & 7.41 & 4.44 & 4.97 & 12.38 & 6.19 \\
\hline 8 & Limnacharis flava $\mathrm{L}$. & 4 & 0.75 & 11.11 & 2.22 & 2.48 & 13.60 & 6.80 \\
\hline 9 & Leersia hexandra Sw. & 1 & 0.50 & 7.41 & 0.56 & 0.62 & 8.03 & 4.01 \\
\hline 10 & Mitella nuda $\mathrm{L}$ & 1 & 0.25 & 3.70 & 0.56 & 0.62 & 4.32 & 2.16 \\
\hline 11 & $\begin{array}{l}\text { Cynodon dactylon (L.) } \\
\text { Pers. }\end{array}$ & 1 & 0.25 & 3.70 & 0.56 & 0.62 & 4.32 & 2.16 \\
\hline 12 & Asystasia gangetica & 2 & 0.25 & 3.70 & 1.11 & 1.24 & 4.95 & 2.47 \\
\hline 13 & Aeschynomene aspera $\mathrm{L}$. & 2 & 0.25 & 3.70 & 1.11 & 1.24 & 4.95 & 2.47 \\
\hline 14 & Ageratum conyzoides & 13 & 0.25 & 3.70 & 7.22 & 8.07 & 11.78 & 5.89 \\
\hline 15 & Digitaria ciliaris & 1 & 0.25 & 3.70 & 0.56 & 0.62 & 4.32 & 2.16 \\
\hline 16 & Titonia & 3 & 0.25 & 3.70 & 1.67 & 1.86 & 5.57 & 2.78 \\
\hline
\end{tabular}

Hasil percobaan pada Tabel 5. dapat diketahui bahwa pada varitas Aryze H6444 Gold ada 15 jenis gulma yang tumbuh. Masing-masing gulma tersebut memiliki nilai analisis dominasi yang tidak sama. INP tertinggi terdapat pada gulma Ludwigia octovalvisyaitu sebesar 45,87 dengan SDR sebesar 22,94. Analsis dominasi gulma sistem SRI pada mulsa sekam padi dapat dilihat pada Tabel 6.

Tabel 6 Analisis dominasi gulma sistem SRI berdasarkan varitas Situ Bangendit

\begin{tabular}{clccccccc}
\hline \multirow{2}{*}{ No. } & \multirow{2}{*}{ Jenis Gulma } & \multicolumn{7}{c}{ Varitas Situ Bangendit } \\
\cline { 3 - 8 } & & $\mathbf{D}$ & $\mathbf{F}$ & $\mathbf{F R}$ & $\mathbf{K}$ & $\mathbf{K R}$ & INP & SDR \\
\hline 1 & Portulaca oleracea $\mathrm{L}$ & 3 & 0.75 & 1.90 & 1.67 & 1.90 & 3.80 & 1.90 \\
2 & Amaranthus spinosus & 1 & 0.25 & 0.63 & 0.56 & 0.63 & 1.27 & 0.63 \\
3 & Eleusine indica & 30 & 7.50 & 18.99 & 16.67 & 18.99 & 37.97 & 18.99 \\
4 & Convolvulus arvensis & 3 & 0.75 & 1.90 & 1.67 & 1.90 & 3.80 & 1.90 \\
5 & Commelina diffusa Burm. f. & 1 & 0.25 & 0.63 & 0.56 & 0.63 & 1.27 & 0.63 \\
6 & Ludwigia octovalvis (Jacq) & $\mathbf{8 6}$ & 21.50 & 54.43 & 47.78 & 54.43 & $\mathbf{1 0 8 . 8 6}$ & $\mathbf{5 4 . 4 3}$ \\
7 & Eclipta alba & 24 & 6.00 & 15.19 & 13.33 & 15.19 & 30.38 & 15.19 \\
8 & Echinachloa crus-galli $(\mathrm{L})$ & 2 & 0.50 & 1.27 & 1.11 & 1.27 & 2.53 & 1.27 \\
9 & Cynodon dactylon (L.) Pers. & 3 & 0.75 & 1.90 & 1.67 & 1.90 & 3.80 & 1.90 \\
10 & Ageratum conyzoides & 3 & 0.75 & 1.90 & 1.67 & 1.90 & 3.80 & 1.90 \\
\hline
\end{tabular}

Hasil percobaan pada Tabel 6.dapat diketahui bahwa pada varitas
Situ Bagendit ada 12 jenis gulma yang tumbuh. Masing - masing gulma 
tersebut memiliki nilai analisis dominasi yang tidak sama. INP tertinggi terdapat pada gulma Ludwigia octovalvis yaitu sebesar
108.86 dengan SDR sebesar 54.43. Hasil analisis dominasi gulma sistem SRI pada mulsa sekam padi dapat dilihat pada Tabel 7.

Tabel 7 Analisis dominasi gulma sistem SRI berdasarkan varitas Siganteng

\begin{tabular}{|c|c|c|c|c|c|c|c|c|}
\hline \multirow{2}{*}{ No. } & \multirow{2}{*}{ Jenis Gulma } & \multicolumn{7}{|c|}{ Siganteng } \\
\hline & & $\mathbf{D}$ & $\mathbf{F}$ & FR & $\mathbf{K}$ & KR & INP & SDR \\
\hline 1 & Amara & 1 & 0.25 & 1.02 & 0.56 & 1.02 & 2.04 & 1.02 \\
\hline 2 & Eleusine $i$ & 22 & 5.50 & 22.45 & 12.22 & 22.45 & 44.90 & 22.45 \\
\hline 3 & Convolvulus arvensis & 1 & 0.25 & 1.02 & 0.56 & 1.02 & 2.04 & 1.02 \\
\hline 4 & Ludwigia octovalvis Jacq & 33 & 8.25 & 33.67 & 18.33 & 33.68 & 67.35 & 33.67 \\
\hline 5 & Eclipta alba & 29 & 7.25 & 29.59 & 16.11 & 29.59 & 59.19 & 29.59 \\
\hline 6 & Echinachloa crus-galli $\mathrm{L}$ & 10 & 2.50 & 10.20 & 5.56 & 10.20 & 20.41 & 10.20 \\
\hline 7 & Limnacharis flava $\mathrm{L}$ & 2 & 0.50 & 2.04 & 1.11 & 2.04 & 4.08 & 2.04 \\
\hline
\end{tabular}

Hasil percobaan pada Tabel 7. dapat diketahui bahwa pada varitas Siganteng ada 6 jenis gulma yang tumbuh. Masing - masing gulma tersebut memiliki nilai analisis dominasi yang tidak sama. INP tertinggi terdapat pada gulma Ludwigia octovalvis yaitu sebesar 67.35 dengan SDR sebesar 33.67.

Pada varitas Aryze H6444 Gold jumlah gulma yang tumbuh sebanyak 16 jenis gulma, pada varitas Situ Bagendit sebanyak 10 jenis gulma dan pada varitas Siganteng sebanyak 7 jenis gulma. Gulma Ludwigia octovalvis memiliki jumlah individu yang terbanyak tumbuh pada setiap jenis varitas yang di tanam. Jumlah gulma Ludwigia octovalvis terendah terdapat pada Varitas Siganteng yaitu 33 individu dibandingkan pada varitas Situ Bagendit yaitu 86 individu dan varitas Aryze H6444 Gold yaitu 50 individu.

Namun jika di lihat dari nilai SDR maka pada varitas Aryze H6444 Gold menunjukkan nilai terendah 22.94 dibandingkan dengan varitas Situ Bagendit 54.43 dan varitas Siganteng 33.67. Hal ini disebabkan jumlah jenis gulma pada varitas Aryze H6444 Gold lebih sedikit dibanding dengan jenis varitas lainnya.

\section{KESIMPULAN}

Varitas Aryze H6444 Gold dan varitas Siganteng menunjukkan hasil terbaik pada penggunaan mulsa plastik, sedangkan varitas Situ Bagendit menunjukkan hasil terbaik pada mulsa jerami padi.

Jenis gulma Ludwigia octovalvis merupakan gulma yang mendominasi pada pemberian mulsa jerami padi, sekam padi dan mulsa plastik. Sedangkan pada mulsa Titonia jenis gulma yang mendominasi adalah gulma Eleusine indica.

Penggunaan mulsa plastik lebih baik dari pada penggunaan mulsa Titonia, mulsa jerami padi dan sekam padi dalam menekan pertumbuhan gulma pada tanaman padi sawah dengan sistem SRI.

\section{DAFTAR PUSTAKA}

Chung, I.M, K.H. Kim, J.K. Ahn, S.B. Lee, S.H. Kim, dan S.J. Hahn. 2003. "Comparison of allelopathic potential of rice leaves, straw, and hull extract on barnygrass". Agron. J. 95: 1063-1070. 
Decentralized Irrigation System Improvement Project in Eastren Region of Indonesia (DISIMP). 2005. "SRI The System of Rice Intensification in East Indonesia". Nippon Koei.JBIC

Departemen Pertanaian. 2007. Uji lapang alsintan mendukung budidaya tanaman padi sawah secara terpadu. www.mekanisasi.litbang.depta n.go.id. Diakses 14 Januari 2007.

FAO. 2004. "Rice and water: a long and diversified story". FAO United Nation. Rome. Italy.

Gomez, K. A. dan A. A. Gomez. 1995. Prosedur Statistik untuk Penelitian Pertanian. (Terjemahan). E. Syamsudin dan J. S. Baharsjah. UI Press. Jakarta. 698 hal

Jatmiko, S.Y., Harsanti S., Sarwoto, dan A.N. Ardiwinata. 2002. Apakah herbisida yang digunakan cukup aman? hlm. 337-348. Dalam J. Soejitno, I.J. Sasa, dan Hermanto (Ed.). Prosiding Seminar Nasional Membangun Sistem Produksi Tanaman Pangan Berwawasan Lingkungan. Pusat Penelitian dan Pengembangan Tanaman Pangan, Bogor.

Lee, L. J. dan Ngim J. 2000. Control of Asystasia intrusa (BI) In Pineapple with Emphasis on
New Techniques. Papper presented at the Seminar and Discussion on the Weed Asystasia, West Johore Agric. Dev. Project, Pontian, 16 pp.

Mayun, I. D. 2007. Efek Mulsa Jerami Padi Dan Pupuk Kandang Sapi TerhadapPertumbuhan Dan Hasil Bawang Merah Di Daerah Pesisir. Agritrop, 26 (1) :33-40

Moenandir, J. 1988. Fisiologi Herbisida (Ilmu Gulma: Buku II). Rajawali Pers. Jakarta. 143 hal

Pitoyo, J. 2006. Mesin Penyiang Gulma Padi Sawah Bermotor. Sinar Tani.Edisi 5-11 Juli 2006. http://www.pustakadeptan.go.id

Sukman, Y. dan Yakup. 2002. Gulma Dan Teknik Pengendaliannya. PT Raja Grafindo Persada. Jakarta. 159 hal.

Umboh H A. 2000. Petunjuk Penggunaan Mulsa. Penebar Swadaya. Jakarta. 98 hal.

Willcox, V. D. 2012. Weed SurveySouthern States Grass Subsection. Proc South Weed Sci. Soc. 57 (3): 420-423.

Zulmardi. 2016. Pengenalian Gulma pada Padi Sawah dengan Pemberian Bahan Organik pada Metode Sri (System of Intensification). Tesis. Program Pascasarjana. Universitas Andalas. Padang. 